\title{
The role of neopterin in patients with primary and metastatic breast cancer: correlation with clinicopathological data
}

\author{
Soheir Rizk Demian, Mona Hamdy El-Sayed*, Amal Sobhy El-Sedfy, Ahmed Saad Ahmed, \\ Fadwa Mohammed Ahmedai \\ From Society for Immunotherapy of Cancer 29th Annual Meeting \\ National Harbor, MD, USA. 6-9 November 2014
}

Breast cancer is the commonest malignancy of women in many parts of the world and comprises $18 \%$ of all female cancers. There is one million new cases in the world each year. Neopterin which is a pteridine produced by activation of monocytes by IFN- $\gamma$ may be used as a marker of immune system activation. The biological function of neopterin is still largely unknown and certain pathophysiologic roles have only recently been elucidated. Therefore, the aim of this work was to investigate the role of neopterin in females with primary and metastatic breast cancer. The obtained results were correlated with different clinicopathological data of those patients. The study population included females with primary and metastatic breast cancer as well as healthy age matched females were taken as a control group. Peripheral blood mononuclear cells were separated from each subject under study by FicollHypaque density gradient centrifugation technique. The isolated cells were cultured with and without PHA and neopterin levels were measured in serum and culture supernatants by ELISA technique. The results showed that neopterin levels were lowest in serum, followed by culture supernatants without PHA and highest in culture supernatants with PHA in each studied group. The mean neopterin values in serum and culture supernatants with PHA of metastatic breast cancer patients were significantly higher than in the primary breast cancer patients and the control group. Our results also indicated that neopterin levels positively correlated with the tumor grade, tumor stage and the presence of metastasis. From all mentioned data it is clear that, measurement of neopterin either in serum or in culture supernatants with or without PHA can give an indication about immunological status of

Medical Research Institute - Alexandria University, Alexandria, Egypt breast cancer patients' response to therapy and early detection of metastasis. It gives an important and valuable prognostic information before surgical intervention is performed.

Published: 6 November 2014

doi:10.1186/2051-1426-2-S3-P147

Cite this article as: Demian et al:: The role of neopterin in patients with primary and metastatic breast cancer: correlation with

clinicopathological data. Journal for ImmunoTherapy of Cancer 2014 2(Suppl 3):P147.
Submit your next manuscript to BioMed Central and take full advantage of:

- Convenient online submission

- Thorough peer review

- No space constraints or color figure charges

- Immediate publication on acceptance

- Inclusion in PubMed, CAS, Scopus and Google Scholar

- Research which is freely available for redistribution
() Biomed Central 